\title{
Planting methods and depths for yacon (Smallanthus sonchifolius) crops
}

\section{Métodos y profundidades de siembra para el cultivo de yacón (Smallanthus sonchifolius)}

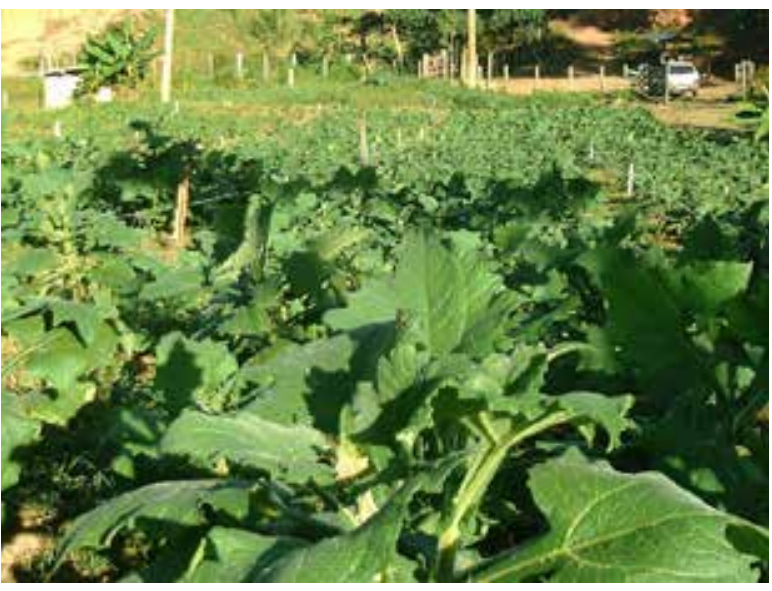

MATEUS AUGUSTO LIMA QUARESMA'

FÁBIO LUIZ DE OLIVEIRA'

JOSÉ FRANCISO TEIXEIRA DO AMARAL ${ }^{1}$

MAGNO DO CARMO PARAJARA²

LEANDRO PIN DALVI

ARIANY DAS GRAÇAS TEIXEIRA ${ }^{3,4}$

Planting depths and methods for Smallanthus sonchifolius crops in Brazil.

Photo: M.A.L. Quaresma

\section{ABSTRACT}

Crop management is vital to sprouting, cycle and productivity in most plants of commercial interest. However, recommendations and information are scarce for yacon cultivation, especially for possible interferences form planting method and depth in crop development and production. Therefore, the objective was to study the influence of the planting methods and depths on yacon tuberous root development and production under high altitude conditions. This experiment used a randomized complete block design, with four replications, in a subdivided plot scheme. The plots consisted of three planting methods (groove, pit and ridge), and the subplots had four planting depths $(5,10,15$, and $20 \mathrm{~cm})$. Evaluations were carried out starting with the sprouting process of the rhizophores to the yield of tuberous roots. The planting methods pit and ridge had lower seedling mortality rates ( 27.5 and $20.2 \%$ lower than groove) and higher yields of tuberous roots ( 31.2 and $21.4 \%$ higher than groove). The planting depths 5 and $10 \mathrm{~cm}$ for the rhizophores were more suitable for yacon cultivation with the three planting methods.

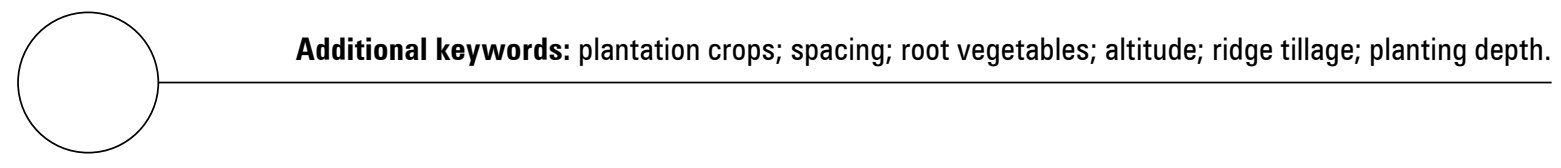

1 Universidade Federal do Espírito Santo, Department of Plant Production, Alegre (Brazil). ORCID Quaresma, M.A.L.: 0000-0003-0622-0955; ORCID Oliveira, F.L.: 0000-0002-1711-6988; ORCID Amaral, J.F.T.: 0000-0003-3027-4830; ORCID Dalvi, L.P.: 0000-0002-2995-8007

2 Universidade Federal de Viçosa, Department of Crop Science, Viçosa (Brazil). ORCID Parajara, M.C.: 0000-0001-6266-883X

3 Instituto Federal do Espirito Santo, campus Santa Teresa, Department of Agronomy, Santa Teresa (Brazil) ORCID Teixeira, A.G.: 0000-0001-8742-521X

4 Corresponding author. arianyteixeira@yahoo.combr 


\section{RESUMEN}

El manejo del cultivo es decisivo en la brotación, el ciclo y productividad de la mayoría de las plantas de interés comercial. Sin embargo, para el cultivo de yacón las recomendaciones e información son escasas, especialmente en lo que respecta a los posibles efectos del método y la profundidad de siembra en el desarrollo y la producción del cultivo. Por lo anterior, el objetivo de este trabajo fue conocer la influencia de los métodos y profundidades de siembra en el desarrollo y producción de raíces tuberosas de yacón en condiciones de gran altitud. El diseño experimental adoptado fue en bloques al azar, con cuatro repeticiones, en un esquema de parcelas divididas, las parcelas principales consistieron de tres métodos de siembra (surcos, hoyos y camas) y las subparcelas fueron las cuatro profundidades de siembra $(5,10,15$ y $20 \mathrm{~cm}$ ). Las evaluaciones se llevaron a cabo desde el proceso de brotación de los rizóforos hasta el rendimiento de las raíces tuberosas. Los métodos de siembra en hoyos y camas mostraron las tasas de mortalidad de plántulas más bajas (27,5 y 20,2\% más bajas que la siembra en surcos) y los rendimientos más altos de raíces tuberosas ( 31,2 y $21,4 \%$ más altas que plantación de surcos). Se demostró que las profundidades de 5 y 10 $\mathrm{cm}$ de rizóforos fueron las más adecuadas para el cultivo de yacón para los tres métodos de plantación.

Palabras clave adicionales: siembra de cultivos; espaciamiento de plantas; vegetales de raíz; altitud; labranza en camas; profundidad de plantación.

Received for publication: 30-05-2019 Accepted for publication: 11-06-2020

INTRODUCTION

Yacon [Smallanthus sonchifolius (Poepp. \& Endl.) H. Robinson] confers several benefits, such as constipation relief, increased mineral absorption, strengthened immune system (Genta et al., 2010), decreased development of colon cancer (Santana and Cardoso, 2008) and disease inhibition, such as Diabetes Mellitus (Albuquerque and Rolim, 2012). As a result, interest in cultivation has increased, along with demand for a management method that conders bigger and more stable production.

Harvest yield is diverse, ranging from 1 to $41 \mathrm{t} \mathrm{ha}^{-1}$ in Ecuador, 7 to $107 \mathrm{t} \mathrm{ha}^{-1}$ in Peru, 25 to $90 \mathrm{t} \mathrm{ha}^{-1}$ in the Czech Republic and 25 to $35 \mathrm{t} \mathrm{ha}^{-1}$ in the United States. In Brazil, yields from 20 to $100 \mathrm{t} \mathrm{ha}^{-1}$ were observed in the State of Espírito Santo, Brazil. Silva et al. (2018a) observed production variation because of edaphoclimatic conditions, with $97.50 \mathrm{t} \mathrm{ha}^{-1}$ (in the mountainous region) and $60.65 \mathrm{t} \mathrm{ha}^{-1}$ (in the lowland region).

These variations in productive yield are attributed to issues related to environmental interference, especially temperature (Silva et al., 2018b) and water availability (Sumiyanto et al., 2012), as well as management, such as the season (Silva et al., 2018a), planting depth, nutrition, and spacing, among others (Seminário et al., 2003).
In Brazil and in the world, technical recommendations are needed for yacon cultivation, especially the optimal method and planting depth for different edaphoclimatic conditions because they can influence crop productivity and vary according to the characteristics of the region.

The method and planting depth can significantly interfere with the budding process and initial development of the plants (Grotta et al., 2008) and, consequently, crop production. The shape and depth of propagule propagation can expose them to different microenvironment conditions, interfering with the development of future plants (Rós, 2017) and affecting crop productivity (Modolo et al., 2010).

Therefore, the objective was to study the influence of planting methods and depths on yacon tuberous root development and production under high altitude conditions.

\section{MATERIAL AND METHODS}

The experiment was carried out in 2016 in "Flor e Mel", Patrimônio da Penha, a district of Divino de São Lourenço in the State of Espírito Santo, Brazil, with the geographic coordinates $20^{\circ} 35^{\prime} 6.0^{\prime \prime}$ South latitude 
and $41^{\circ} 46$ '18.2" West longitude, and an altitude of $1,098 \mathrm{~m}$ a.s.l. This municipality is in the mountain region of Espírito Santo, which has a mountain climate (tropical altitude) with two well-defined seasons during the year, one hot and rainy in October to March and the other cold and dry in April to September (Pezzopane et al., 2012). The maximum monthly temperatures ranged from 26 to $28^{\circ} \mathrm{C}$, and the minimum temperatures were 12 to $18^{\circ} \mathrm{C}$. The total rainfall during the experiment was $760 \mathrm{~mm}$, with uneven distribution and low volume between the months of May to August (INMET, 2016).

The area was fallow for nine months, with a high number of ferns (Pteridium arachnoideum (Kaulf.) Maxon), a soil indicator of high acidity. For the initial soil tillage, weeding was done with a costal brush, and, after one week, the soil was plowed three times to about $20 \mathrm{~cm}$ using a hoe, incorporating the weed biomass to the soil.

The soil of the area was classified as Cambisolo $\mathrm{Tb}$ Distrophic, loamy clay texture (Santos et al., 2013), and the chemical and physical analysis showed the following characteristics in the 0 to $20 \mathrm{~cm}$ layer: $\mathrm{pH}$ 5.21 in water; $3.58 \mathrm{mg} \mathrm{dm}^{-3}$ of $\mathrm{P}\left(\right.$ Mehlich $\left._{1}\right) ; 22.00$ $\mathrm{mg} \mathrm{dm}{ }^{-3}$ of $\mathrm{K} ; 2.59 \mathrm{cmol}_{c} \mathrm{dm}^{-3}$ of $\mathrm{Ca} ; 0.84 \mathrm{cmol}_{c} \mathrm{dm}^{-3}$ of $\mathrm{Mg} ; 0.05 \mathrm{cmol}_{\mathrm{c}} \mathrm{dm}^{-3}$ of $\mathrm{Al} ; 7.59 \mathrm{cmol}_{\mathrm{c}} \mathrm{dm}^{-3}$ of $\mathrm{H}^{+}$ Al; $4.41 \mathrm{cmol}_{c} \mathrm{dm}^{-3}$ of SB; $4.46 \mathrm{cmol}_{c} \mathrm{dm}^{-3}$ of t; 12.00 $\mathrm{cmol}_{\mathrm{c}} \mathrm{dm}^{-3}$ of T; $36.76 \%$ V; $23 \%$ sand, $26 \%$ silt, $51 \%$ clay and $1.20 \mathrm{dag} \mathrm{kg}^{-1}$ of OM.

Yacon rhizophores from a production area in the municipality of Santa Maria do Jetibá/ES were harvested $3 \mathrm{~d}$ before planting. The rhizophores were selected and fractionated into $40-50 \mathrm{~g}$ pieces, washed in running water and immersed in a sodium hypochlorite solution $(5 \% \mathrm{v} / \mathrm{v})$ for $10 \mathrm{~min}$. After treatment, the rhizophores were dried for $2 \mathrm{~d}$ in a ventilated and shaded place.

The yacon was planted in April, which is a more productive period Silva et al. (2018a), in crops in this region, with cultivation extended to December, ending with the harvest. The fertilization was carried out by applying $200 \mathrm{~g}$ of tanned bovine manure at planting and $150 \mathrm{~g}$ for the cover fertilization, $90 \mathrm{~d}$ after sowing. This amount was equivalent to 152.24 $\mathrm{kg} \mathrm{ha}{ }^{-1}$ of nitrogen (approximating the $150 \mathrm{~kg} \mathrm{ha}^{-1}$ recommended by Amaya (2000) based on nutrient contents in manure $\left(1.74 \mathrm{~N}, 0.63 \mathrm{~K}_{2} \mathrm{O}\right.$ and $0.35 \%$ $\left.\mathrm{P}_{2} \mathrm{O}_{5}\right)$ ).
After planting, monthly weeding was done with costal brush cutters, cutting between the plants, keeping residues below the soil surface. Sprinkler irrigation was used to supplement the monthly precipitation. However, during the months of May to August, there was a severe drought in the region that limited the use of irrigation.

The experiment design was a randomized complete block design, with four replications, in a subdivided plot scheme. The plots consisted of three planting methods: grooved, pit, and ridges. The subplots had four planting depths: $5,10,15$, and $20 \mathrm{~cm}$.

The planting grooves were $20 \mathrm{~cm}$ wide and $20 \mathrm{~cm}$ deep, and the ridges were $50 \mathrm{~cm}$ wide and $40 \mathrm{~cm}$ high (both done with hoes). The pits had a radius of $10 \mathrm{~cm}$ and depth of $20 \mathrm{~cm}$ (made with hand diggers).

The experiment subplot had 28 plants, with an area of $11.2 \mathrm{~m}^{2}(3.5 \times 3.2 \mathrm{~m})$, providing 10 useful plants for the evaluations, for a total of 600 useful plants out of 1,680 plants in $672 \mathrm{~m}^{2}$. The planting was carried out at a spacing of $0.8 \mathrm{~m}$ between cultivation lines and $0.5 \mathrm{~m}$ between plants, representing a planting density of 25,000 plants/ha, based on the planting densities described by Seminário et al. (2003).

The following characteristics were analyzed: sprouting rate index (SRI), vigorous sprouting rate (VSR), average sprouting time (AST), seedling mortality rate (SMR), leaf area at 120 and $240 \mathrm{~d}$ after planting (LA1 and LA2), dry mass of tuberous roots (DMTR), number of rhizophores and tuberous roots per plant (NR and TRP), leaf dry matter, and tuberous root yield (TRY).

The initial development was evaluated every $15 \mathrm{~d}$, always at the same time $(8 \mathrm{~h})$, for $75 \mathrm{~d}$ after planting (DAP). The evaluation methodology from Maguire (1962) was used, according to the vegetative stages: "Green Tip" (GT), appearance of bud coloring modifications, with a greenish tip), and "Open Bud" (OB), based on these vegetative stages. The following variables were calculated:

- Average sprouting time (AST): mean number of days spent between experiment setup on each date and detecting the vegetative stages "Green Tip" (GT) (appearance of bud coloring modifications, with the greenish tip); 
- Sprouting rate index (SRI): occurrence of sprouting buds in time given the equation (1):

$S R I=S\left(\frac{n i}{t i}\right)$ (buds per day)

where, $n i$ is number of buds that reached the GT stage at time " $i$ " and ti time in days after the test $\operatorname{setup~}(i=1$ to 45$)$;

- Final sprouting rate (FSR): percentage of rhizophores sections with buds that reached the GT stage;

- Vigorous Sprouting Rate (VSR): percentage of rhizophores sections with buds in the GT stage that progressed to the "Open Bud" (OP) stage (open leaf appearance), during the analysis, given with the equation (2):

VSR $=(\%$ of rhizophores section with GT stages $) \times 100 /$ TF $(2)$

- Mortality rate (MR): percentage of rhizophores sections that remained alive and vigorous until the end of the evaluations.

The leaf area measurements were taken indirectly using the width and length of each leaf, estimating the total leaf area per plant according to the model of indirect determination proposed by Erlacher et al. (2016).

The plant dry matter mass of each plant part was obtained with a digital scale, $0.01 \mathrm{~g}$ precision, and ovendried samples, done with forced air circulation at a temperature of $65^{\circ} \mathrm{C}$ until constant mass.

The data were initially tested for normality assumptions of the residues (Shapiro-Wilk test) and homogeneity among variances (Bartlett's test). Then, an analysis of variance was performed. The averages were compared with the Tukey test. In all tests ( $t$ and F), $P<0.05$ was used as the main significance value.

\section{RESULTS AND DISCUSSION}

When analyzing the effect of the planting depths in each method, it was observed that the rhizophore sprouting rate index (SRI) were higher in the depths 5 and $10 \mathrm{~cm}$ in the planting ridges and pits and at 5 $\mathrm{cm}$ in the grooves. This result reflected the average sprouting time (AST) for the same planting methods and depths (Tab. 1).

Table 1. Sprouting rate index, average sprouting time, vigorous sprouting rate and rhizophore mortality rate in yacon with different planting methods and depths. UFES, Divino de São Lourenço, ES, 2016.

\begin{tabular}{|c|c|c|c|c|c|c|}
\hline \multirow{3}{*}{ Depth (cm) } & \multicolumn{6}{|c|}{ Planting method } \\
\hline & Grooves & Ridges & Pits & Grooves & Ridges & Pits \\
\hline & \multicolumn{3}{|c|}{ Sprouting rate index (buds/d) } & \multicolumn{3}{|c|}{ Average sprouting time (d) } \\
\hline 5 & $1.50 \mathrm{a}$ & $1.98 \mathrm{a}$ & $1.64 \mathrm{a}$ & $42.49 \mathrm{~b}$ & $28.54 b$ & $35.11 \mathrm{c}$ \\
\hline 10 & $1.31 \mathrm{a}$ & $1.51 \mathrm{~b}$ & $1.53 \mathrm{a}$ & $43.38 b$ & $32.86 \mathrm{~b}$ & $48.80 \mathrm{~b}$ \\
\hline 15 & $0.93 \mathrm{~b}$ & $1.02 \mathrm{c}$ & $1.02 \mathrm{~b}$ & $63.54 \mathrm{a}$ & $50.10 \mathrm{a}$ & $67.40 \mathrm{a}$ \\
\hline 20 & $0.81 \mathrm{~b}$ & $0.76 \mathrm{c}$ & $0.87 \mathrm{~b}$ & $70.10 \mathrm{a}$ & 60.67 a & $74.94 \mathrm{a}$ \\
\hline Mean & $1.14 \mathrm{~B}$ & $1.32 \mathrm{~A}$ & $1.26 \mathrm{~A}$ & $54.88 \mathrm{AB}$ & $43.04 \mathrm{~B}$ & $56.56 \mathrm{~A}$ \\
\hline CV $(\%)$ & 10.87 & & & 13.05 & & \\
\hline SE & 0.04 & & & 3.01 & & \\
\hline Depth (cm) & \multicolumn{3}{|c|}{ Vigorous sprouting rate (\%) } & \multicolumn{3}{|c|}{ Mortality rate (\%) } \\
\hline 5 & $65.12 a^{1}$ & $67.19 \mathrm{a}$ & $85.74 \mathrm{a}$ & $23.75 \mathrm{a}$ & $15.16 b$ & $13.54 b$ \\
\hline 10 & $58.31 \mathrm{a}$ & $68.47 \mathrm{a}$ & 87.46 a & $25.83 \mathrm{a}$ & $12.45 b$ & $10.82 b$ \\
\hline 15 & $39.31 \mathrm{~b}$ & $33.75 b$ & $62.66 \mathrm{~b}$ & $28.80 \mathrm{a}$ & $28.12 \mathrm{a}$ & $26.04 \mathrm{a}$ \\
\hline 20 & $37.18 b$ & $32.31 \mathrm{~b}$ & $52.35 b$ & $30.25 a$ & $30.94 \mathrm{a}$ & $28.32 \mathrm{a}$ \\
\hline Mean & $49.98 \mathrm{~B}$ & 50.68 B & $71.80 \mathrm{~A}$ & $27.16 \mathrm{~A}$ & $21.67 \mathrm{~B}$ & $19.68 \mathrm{~B}$ \\
\hline CV(\%) & 13.05 & & & 18.52 & & \\
\hline SE & 2.56 & & & 3.48 & & \\
\hline
\end{tabular}

Means with different lowercase letters for depth and capital letters for planting methods indicate a significant statistical difference according to the Tukey's test $(P \leq 0.05)(n=4) ; C V$ : coefficients of variation; SE: standard error of estimates. 
The vigorous sprouting rate (VSR) had a similar behavior as the mean sprouting time. The best VSR was observed at the depths 5 and $10 \mathrm{~cm}$ in the three applied methods. The mortality rate was always larger at the depths 15 and $20 \mathrm{~cm}$, except for the groove planting, in which there was no significant difference for the different planting depths (Tab. 1).
For crop development, the planting methods with rows or grooves had no significant differences for the total plant leaf area (LA), as compared to the studied planting depths (5 to $20 \mathrm{~cm}$ ). However, when using the ridge planting method, a higher LA were observed in the plants grown with the depths 5 and $10 \mathrm{~cm}$ (Tab. 2).

Table 2. Leaf area of yacon plants with different planting methods and depths on two dates during the cycle. UFES, Divino de São Lourenço, ES, 2016.

\begin{tabular}{|c|c|c|c|c|c|c|}
\hline \multirow{4}{*}{ Depth (cm) } & \multicolumn{6}{|c|}{ Planting methods } \\
\hline & Grooves & Ridges & Pits & Grooves & Ridges & Pits \\
\hline & \multicolumn{3}{|c|}{120 days after planting } & \multicolumn{3}{|c|}{240 days after planting } \\
\hline & \multicolumn{6}{|c|}{ Leaf area $\left(\mathrm{cm}^{2}\right)$} \\
\hline 5 & $93.69 \mathrm{a}$ & $173.25 \mathrm{a}$ & $143.28 \mathrm{a}$ & $122.76 \mathrm{a}$ & $168.35 \mathrm{a}$ & $164.54 \mathrm{a}$ \\
\hline 10 & $80.16 a$ & $154.28 \mathrm{a}$ & $133.63 \mathrm{a}$ & $120.29 a$ & $159.82 a b$ & $152.07 \mathrm{a}$ \\
\hline 15 & $79.35 \mathrm{a}$ & $125.30 \mathrm{~b}$ & $127.86 \mathrm{a}$ & $123.51 \mathrm{a}$ & $131.51 \mathrm{bc}$ & $148.47 \mathrm{a}$ \\
\hline 20 & $73.72 \mathrm{a}$ & $112.23 b$ & 119.87 a & $109.58 \mathrm{a}$ & $126.43 \mathrm{c}$ & $148.82 \mathrm{a}$ \\
\hline Mean & $81.70 \mathrm{~B}$ & $141.26 \mathrm{~A}$ & $131.16 \mathrm{~A}$ & $119.03 \mathrm{~A}$ & $146.90 \mathrm{~A}$ & $153.47 \mathrm{~A}$ \\
\hline CV (\%) & \multicolumn{3}{|c|}{11.45} & \multicolumn{3}{|c|}{10.66} \\
\hline SE & \multicolumn{3}{|c|}{7.12} & \multicolumn{3}{|c|}{7.30} \\
\hline
\end{tabular}

Means with different lowercase letters for depth and capital letters for planting methods indicate a significant statistical difference according to the Tukey's test $(P \leq 0.05)(n=4) ; C V$ : coefficients of variation; SE - standard error of estimates.

Table 3. Dry mass of aerial part, tuber roots, rhizophores and number of rhizophores of yacon plants with different planting methods and depths. UFES, Divino de São Lourenço, ES, 2016.

\begin{tabular}{|c|c|c|c|c|c|c|}
\hline \multirow{3}{*}{ Depth (cm) } & \multicolumn{6}{|c|}{ Planting method } \\
\hline & Grooves & Ridges & Pits & Grooves & Ridges & Pits \\
\hline & \multicolumn{3}{|c|}{ Aerial part dry mass (t ha-1) } & \multicolumn{3}{|c|}{ Tuberous roots dry mass $\left(\mathrm{t} \mathrm{ha}^{-1}\right)$} \\
\hline 5 & 0.18 a & $0.25 \mathrm{a}$ & $0.20 \mathrm{a}$ & $0.17 \mathrm{a}$ & $0.19 \mathrm{a}$ & $0.22 \mathrm{a}$ \\
\hline 10 & $0.12 \mathrm{~b}$ & $0.15 b$ & $0.13 b$ & $0.14 \mathrm{a}$ & $0.18 \mathrm{a}$ & $0.21 \mathrm{a}$ \\
\hline 15 & $0.13 \mathrm{~b}$ & $0.16 \mathrm{~b}$ & $0.14 \mathrm{~b}$ & $0.07 \mathrm{~b}$ & $0.11 \mathrm{~b}$ & $0.10 \mathrm{~b}$ \\
\hline 20 & $0.11 \mathrm{~b}$ & $0.14 b$ & $0.11 \mathrm{~b}$ & $0.06 \mathrm{~b}$ & $0.07 \mathrm{c}$ & $0.9 \mathrm{~b}$ \\
\hline Mean & $0.13 \mathrm{~A}$ & $0.17 \mathrm{~A}$ & $0.14 \mathrm{~A}$ & $0.11 \mathrm{~B}$ & $0.14 \mathrm{AB}$ & $0.16 \mathrm{~A}$ \\
\hline CV (\%) & \multicolumn{3}{|c|}{13.20} & \multicolumn{3}{|c|}{15.81} \\
\hline SE & \multicolumn{3}{|c|}{0.01} & \multicolumn{3}{|c|}{0.02} \\
\hline Depth (cm) & \multicolumn{3}{|c|}{ Rhizophores dry mass (t ha-1) } & \multicolumn{3}{|c|}{ Number of rhizophores } \\
\hline 5 & $0.20 \mathrm{a}$ & $0.31 \mathrm{a}$ & $0.34 \mathrm{a}$ & $3.10 \mathrm{a}$ & $3.84 \mathrm{a}$ & $3.87 \mathrm{a}$ \\
\hline 10 & $0.16 b$ & $0.26 b$ & $0.28 \mathrm{~b}$ & $2.25 b$ & $3.30 a b$ & $3.23 a b$ \\
\hline 15 & $0.14 b$ & $0.27 \mathrm{~b}$ & $0.26 \mathrm{~b}$ & $1.51 \mathrm{c}$ & $2.43 \mathrm{~b}$ & $2.42 \mathrm{~b}$ \\
\hline 20 & $0.14 \mathrm{~b}$ & $0.24 \mathrm{~b}$ & $0.25 b$ & $1.48 \mathrm{c}$ & $2.35 b$ & $2.23 \mathrm{~b}$ \\
\hline Mean & $0.16 \mathrm{~B}$ & $0.27 \mathrm{~A}$ & $0.28 \mathrm{~A}$ & $2.09 \mathrm{~B}$ & $2.98 \mathrm{~A}$ & $2.91 \mathrm{~A}$ \\
\hline CV (\%) & \multicolumn{3}{|c|}{16.79} & \multicolumn{3}{|c|}{14.67} \\
\hline SE & \multicolumn{3}{|c|}{0.03} & \multicolumn{3}{|c|}{0.10} \\
\hline
\end{tabular}

Means with different lowercase letters for depth and capital letters for planting methods indicate a significant statistical difference according to the Tukey's test $(P \leq 0.05)(n=4)$; CV: coefficients of variation; SE: standard error of estimates. 
It is also observed that, in general, only the plants cultivated in grooves had a lower total LA, up to half of the cycle (120 DAP), but, at the end of the cycle (240 DAP), the plants in all the methods did not present statistical differences (Tab. 2).

In all cultivation methods, the plants that presented the highest aerial part and rhizophores were planted at the $5 \mathrm{~cm}$ depth. As the plant depth increased, the values decrease (Tab. 3).

A similar behavior was observed in the dry mass of tuberous roots; however, the highest values were seen in all cultivation methods with the 5 and $10 \mathrm{~cm}$ depths. Notably, the groove method, regardless of the depth, presented the lowest accumulation of dry root mass (Tab. 3).

All cultivation methods had a decrease in the amount of rhizophores per plant, as the planting depth increased. However, the groove planting, regardless of the depth, had the lowest number of rhizophores (Tab. 3).

The tuber root numbers per plant were also higher in all methods in the shallower layers. For the groove and ridge cultivations, the highest number of tuberous roots per plant was observed at the $5 \mathrm{~cm}$ depth, while, for the pit planting method, the highest number was seen at the 5 and $10 \mathrm{~cm}$ depths (Tab. 4).

The plants had higher productivity when cultivated in grooves at the $5 \mathrm{~cm}$ depth and when cultivated in ridges and pits at the 5 and $10 \mathrm{~cm}$ depths (Tab. 4).
When comparing the plants cultivated in grooves with those that developed in ridges and pits, higher productivity was observed, regardless of the planting depth (Tab. 4).

However, the yields, in general, were well below those obtained by Silva et al. (2019), who observed an average of $77 \mathrm{t} \mathrm{ha}^{-1}$ (in the same region), as a result of the severe drought in the region, generating an extreme stress with the decrease in soil moisture, which is the principal factor for the formation of tuberous roots (Fernandéz et al., 2006). This stress occurred during the phenological stage of the culture, with the greatest branching (growth of the aerial part) and the beginning of the formation of tuberous roots (Silva et al., 2018a). Thus, the plants had less shoot development, less leaf area, and lower productivity.

Even so, these results indicated that, under high altitude conditions, planting at shallower depths (from 5 to $10 \mathrm{~cm}$ ) may provide more favorable conditions for the initial establishment of a crop, which will directly impact the yield. This behavior may be related to the several factors, such as greater ease of soil disruption above the propagule, higher temperatures and thermal amplitudes that may favor the rhizophores sprouting process, facilitating the initial establishment of a crop and positively influencing production (Alves et al., 2014; Rós, 2017).

The environmental temperature and, consequently, the soil temperature, besides being able to modify plant metabolism, change soil moisture dynamics in the soil-plant system, which directly interferes with

Table 4. Number and productivity of tuberous roots of yacon plants with different planting methods and depths. UFES, Divino de São Lourenço, ES, 2016.

\begin{tabular}{|c|c|c|c|c|c|c|}
\hline \multirow{3}{*}{ Depth $(\mathrm{cm})$} & \multicolumn{6}{|c|}{ Planting methods } \\
\hline & Grooves & Ridges & Pits & Grooves & Ridges & Pits \\
\hline & \multicolumn{3}{|c|}{ Number of tuberous roots } & \multicolumn{3}{|c|}{ Tuberous roots productivity $\left(\mathrm{t} \mathrm{ha}^{-1}\right)$} \\
\hline 5 & $3.69 \mathrm{a}$ & $5.09 \mathrm{a}$ & $2.85 \mathrm{a}$ & $1.87 \mathrm{a}$ & $2.04 \mathrm{a}$ & $2.34 \mathrm{a}$ \\
\hline 10 & $2.90 \mathrm{~b}$ & $3.64 \mathrm{~b}$ & $3.39 \mathrm{a}$ & $1.47 \mathrm{~b}$ & $1.94 \mathrm{a}$ & $2.19 a$ \\
\hline 15 & $1.42 \mathrm{c}$ & $3.14 b$ & $2.07 \mathrm{~b}$ & $0.77 \mathrm{c}$ & $1.17 \mathrm{~b}$ & $0.94 b$ \\
\hline 20 & $1.45 c$ & $1.69 \mathrm{c}$ & $1.82 b$ & $0.64 \mathrm{c}$ & $0.78 \mathrm{c}$ & $0.89 \mathrm{~b}$ \\
\hline Mean & $2.34 \mathrm{~B}$ & $3.39 \mathrm{~A}$ & $2.53 \mathrm{~B}$ & $1.19 B$ & $1.46 \mathrm{AB}$ & $1.59 \mathrm{~A}$ \\
\hline CV (\%) & \multicolumn{3}{|c|}{13.30} & \multicolumn{3}{|c|}{14.65} \\
\hline SE & \multicolumn{3}{|c|}{0.10} & \multicolumn{3}{|c|}{0.07} \\
\hline
\end{tabular}

Means with different lowercase letters for depth and capital letters for planting methods indicate a significant statistical difference according to the Tukey's test $(P \leq 0.05)(n=4)$; CV: coefficients of variation; SE: standard error of estimates. 
plant growth (Kirkham, 2005; Teodoro et al., 2011). Silva et al. (2018b) showed that yacon had better development and production, with lower temperature conditions and increased soil moisture, in different cover crops strategies.

In the cultivation methods, regardless of the planting depths of the rhizophores, the cultivations in ridges presented the best results (sometimes resembling the pit method) in the initial establishment of the plants (greater sprouting rate index, greater vigorous sprouting rate and lower mortality rates). The same was observed in the final production (greater number and productivity of tuberous roots).

These results are related to the better soil condition achieved with the ridge and pit methods, mainly because of the possibility of obtaining a less compacted bed, which may have favored root growth, with positive effects on the yacon development and production.

Yacon is included in the vegetable group that produces subterranean reserve organs (roots, rhizomes, tubers and bulbs), is sensitive to soil compaction, inadequate aeration or poor drainage (Howeler et al., 1993), and, therefore, responds better to planting methods and soil preparation that avoid these conditions, as shown in studies on potato (Fontes et al., 2007), cassava (Pequeno et al., 2007; Otsubo et al., 2012) and sweet potato (Rós, 2017). Thus, the method chosen for soil preparation, as well as the planting method, can directly interfere with the success of these crops.

\section{CONCLUSIONS}

Under the high altitude conditions, the planting methods pits and ridges provided greater productivity of tuberous roots than the cultivation in grooves.

The depths 5 and $10 \mathrm{~cm}$ provided better initial establishment of the plants and higher yacon yields.

\section{ACKNOWLEDGMENT}

The authors are grateful to the Conselho Nacional de Desenvolvimento Científico e Tecnológico (CNPq) and the Fundação de Amparo à Pesquisa e Inovação do Espírito Santo (FAPES), for financial support, and $\mathrm{CNPq}$, for the second author's research grant.
Conflict of interests: The manuscript was prepared and reviewed with the participation of the authors, who declare that there exists no conflict of interest that puts at risk the validity of the presented results.

\section{BIBLIOGRAPHIC REFERENCES}

Albuquerque, E.N. and P.M. Rolim. 2012. Potencialidades do yacon (Smallanthus sonchifolius) no diabetes Mellitus. Rev. Ciênc. Méd. 20(3), 99-108. Doi: 10.24220/2318-0897v20n3/4a584

Alves, A.U., E.A. Cardoso, T.F. Alixandre, I.H.L. Cavalcante, and M.Z. Beckmann-Cavalcante. 2014. Emergência de plântulas de fava em função de posições e profundidades de semeadura. Biosci. J. 30(1), 33-42.

Amaya, J.E. 2000. Efeitos de doses crescentes de nitrogenio e potássio na produtividade de yacon (Polymnia sonchifolia Poep. \& Endl.). MSc thesis. Faculdade de Ciências Agronômicas, Universidade Estadual Paulista, São Paulo, Brazil.

Erlacher, W.A., F.L. Oliveira, G.S. Fialho, D.M.N. Silva, and A.H. Carvalho. 2016. Modelos de determinação indireta da área foliar em yacon. Hortic. Bras. 34(3), 422427. Doi: 10.1590/S0102-05362016003019

Fontes, P.C.R., J.C.S. Nunes, H.C. Fernandes, and E.F. Araújo. 2007. Características físicas do solo e produtividade da batata dependendo de sistemas de preparo do solo. Hortic. Bras. 25(3), 335-339. Doi: 10.1590/ S0102-05362007000300007

Genta, S.B., W.M. Cabrera, M.I. Mercado, A. Grau, C.A. Catalán, and S.S. Sánchez. 2010. Hypoglycemic activity of leaf organic extracts from Smallanthus sonchifolius: constituents of the most active fractions. Chem.-Biol. Interact. 185(2), 143-152. Doi: 10.1016/j. cbi.2010.03.004

Grotta, D.C.C., C.E.A. Furlani, R.P. Silva, G.N. Reis, J.W. Cortez, and P.J. Alves. 2008. Influência da profundidade de semeadura e da compactação do solo sobre a semente na produtividade do amendoim. Ciênc. Agrotecnol. 32(2), 547-552. Doi: 10.1590/ S1413-70542008000200031

Howeler, R.H., H.C. Ezumah, and D.J. Midmore. 1993. Tillage systems for root and tuber crops in the tropics. Soil Till. Res. 27(4), 211-240. Doi: 10.1016/0167-1987(93)90069-2

INMET, Instituto Nacional de Meteorologia. 2016. BDMEP Dados históricos. In: http://www.inmet.gov.br/ portal/index.php?r=bdmep/bdmep; consulted: July, 2013.

Kirkham, M.B. 2005. Principles of soil and plant water relations. Elsevier Academic Press, Amsterdam.

Maguire, J.D. 1962. Speed of germination - aid in selection and evaluation for seedling emergence and vigor. Crop Sci. 2(2), 76-177. Doi: 10.2135/ cropsci1962.0011183X000200020033x 
Modolo, A.J., E. Trogello, A.L. Nunes, H.C. Fernandes, J.C.M. Silveira. and M.P. Dambrós. 2010. Efeito de cargas aplicadas e profundidades de semeadura no desenvolvimento da cultura do feijão em sistema plantio direto. Ciênc. Agrotecnol. 34(3), 739-745. Doi: 10.1590/S1413-70542010000300029

Otsubo, A.A., O.R. Brito, D.P. Passos, H.S. Araújo, F.M. Mercante, and V.H.N. Otsubo. 2012. Formas de preparo de solo e controle de plantas daninhas nos fatores agronômicos e de produção da mandioca. Semina: Ciênc. Agrár. 33(6), 2241-2246. Doi: 10.5433/1679-0359.2012v33n6p2241

Pequeno, M.G., O.S. Vidigal Filho, C. Tormena, M. Kvitschal, and M. Manzotti. 2007. Efeito do sistema de preparo do solo sobre características agronômicas da mandioca (Manihot esculenta Crantz). Rev. Bras. Eng. Agríc. Ambient. 11(3), 476-481. Doi: 10.1590/ S1415-43662007000500005

Pezzopane, J.E.M., F.S. Castro, J.R.M. Pezzopane, and R.A. Cecílio. 2012. Agrometeorologia: aplicações para o Espírito Santo. CAUFES, Alegre, ES.

Rós, A.B. 2017. Sistemas de preparo do solo para o cultivo da batata-doce. Bragantia 76(1), 113-124. Doi: 10.1590/1678-4499.607

Santana, I. and M.H. Cardoso. 2008. Raiz tuberosa de yacon (Smallanthus sonchifolius): potencialidade de cultivo, aspectos tecnológicos e nutricionais. Ciênc. Rural 38(3), 898-905. Doi: 10.1590/S0103-84782008000300050

Santos, H.G., P.K.T. Jacomine, L.H.C. Anjos, V.A. Oliveira, J.F. Lumbreras, M.R. Coelho, J.A. Almeida, T.J.F. Cunha, and J.B. Oliveira. 2013. Sistema brasileira de classificação de solos. Embrapa, Brasilia.
Seminário, J., M. Valderrama, and I. Manrique. 2003. El yacon: fundamentos para el aprovechamiento de un recurso promisorio. Centro International de la Papa (CIP); Universidad Nacional de Cajamarca; Agencia Suiza para el Desarrollo y la Cooperación (COSUDE), Lima.

Silva, D.M.N., F.L. Oliveira, P.C. Cavatte, and M.A.L. Quaresma. 2018a. Growth and development of yacon in different periods of planting and growing conditions. Acta Sci. Agron. 40, 1-9. Doi: 10.4025/actasciagron. v40i1.39442

Silva, D.M.N., C.H.P. Venturim, M.E.O.V. Capucho, F.L. Oliveira, and E.S. Mendonça. 2018b. Impact of soil cover systems on soil quality and organic production of yacon. Sci. Hortic. 235, 407-412. Doi: 10.1016/j. scienta.2018.03.024

Silva, D.M.N., F.L. Oliveira, M.A.L. Quaresma, W.A. Erlacher, and T.P. Mendes, 2019. Yacon production at different planting seasons and growing environments. Biosci. J. 35(4), 992-1001. Doi: 10.14393/ bj-v35n4a2019-42091.

Sumiyanto, J., F.E. Dayan, A.L. Cerdeira, Y.H. Wang, I.A. Khan, and R.M. Moraes. 2012. Oligofructans content and yield of yacon (Smallanthus sonchifolius) cultivated in Mississippi. Sci. Hortic. 148, 83-88. Doi: 10.1016/j. scienta.2012.09.020

Teodoro, R.B., F.L. Oliveira, D.M.N. Silva, C. Fávero, and M.A.L. Quaresma. 2011. Leguminosas herbáceas perenes para utilização como coberturas permanentes de solo na Caatinga Mineira. Rev. Ciênc. Agron. 42(2), 292-300. Doi: 10.1590/S1806-66902011000200006 